\title{
Division changes with the needs of Californians
}

\author{
W.R. GOMES \\ Vice President \\ Agriculture and Natural Resources
}

I n January 1994, an earthquake measuring 6.6 on the Richter scale rocked Northridge. Within 48 hours, UC Cooperative Extension had disseminated a series of Spanish-language disaster aid radio spots, providing public safety information to Latino disaster victims, and their friends and families, statewide.

This vital communications program, with a potential audience of 8.6 million, is one example of how profoundly Division programs have changed since UC was founded 128 years ago. In 1868, California was an agrarian society of about 500,000 people. One in every five was a farmer. The far-reaching Morrill Act of 1862 had begun to foster a powerful partnership between land-grant universities and farmers; it would lead to quantum gains in agricultural productivity.

Agriculture is still this state's leading economic generator - a $\$ 22$ billion enterprise in 1995, contributing $\$ 70$ billion to the state's economy. But today, less than $2 \%$ of Californians are directly involved in farming. More than $90 \%$ of the state's residents are urban dwellers. The Division's programs in human, natural and agricultural resources must operate in a radically changed environment, addressing the complex problems of 32 million Californians.

More and more, the Division's work is shaped by population growth. California's population will double to 63 million by 2040 . This growth will blur urban-rural distinctions and bring increasing convergence to the interests of all Californians. While we are different, we have the same interests, whether in ensuring safe food production, preserving the natural environment and resources, or contributing to strong homes, families and youth.

In the early days, the Division's 4-H programs taught farm youth responsibility, leadership and good citizenship. Today 4-H has expanded to serve urban as well as rural areas. Los Angeles County's 4-H After School Activity Program, for instance, reaches youth in low-income housing projects, serving 12,200 children at 24 sites.

Natural resource conservation cannot be separated from agriculture, and Division faculty are playing an increasing role in the resolution of environmental concerns. For instance, UC scientists recently oversaw a detailed scientific assessment of the fragile Sierra Nevada Mountain Range ecosystem under a $\$ 7$ million grant from the U.S. Forest Service. Critical findings and strategies to manage the effects of population growth are now in use by affected communities.

Traditional agricultural research and extension have also changed in light of California's changing demographics. Latinos today comprise $91 \%$ of the agricultural work force in California, and are increasingly assuming positions as farm supervisors, managers and owners. Other new clientele include farmers who have immigrated from Southeast Asia and India.
A recent survey of county offices and DANR special programs identified 35 counties and 7 statewide programs which support outreach to non-English speaking growers and farmworkers in California. For instance:

- UC's IPM Project has conducted more than 120 workshops since 1994 - nearly 50 in Spanish - to certify the state's pesticide handling and pesticide safety instructors. These 2,000-plus UC certified instructors have trained over 750,000 farmworkers and pesticide handlers, most of whom are Spanish-speaking;

- UC's Small Farm Program has six bilingual farm advisors working with Latino and Southeast Asian growers, as well as English-speaking clientele;

- The Agricultural Personnel Management Program has made extensive use of Spanish when providing information through workshops, office visits and handout materials.

- DANR Communication Services provides UC publications, videos and slide sets translated into Spanish and several other languages, including Hmong, Laotian, Cambodian and Punjabi.

- The bilingual Illustrated Guide to Pesticide Safety/Guia Ilustrada para el Uso Seguro de Pesticidas, produced by DANR and used by pesticide training instructors across California, has sold more than 100,000 copies.

Even though Division research and programs have made historic contributions to the state and its development, government funding for UC has waned. In the past 5 years, major budget reductions, combined with personnel cuts on campuses and in counties, have had a profound impact on the Division.

Despite these setbacks, Division personnel are employing numerous strategies to meet their land-grant commitments. These include expanding UC-sponsored "training-the-trainers" programs to increase the number of qualified people providing educational outreach — such as Master Gardeners or Master Food Preservers.

In the future, we will continue to look for support from our industry partners, and we will strive to increase our share of funding through competitive grants. It will not be an easy time, but a time of change.

The Division today is very different from the Division at its birth 128 years ago, but it still plays a critical role in meeting the needs of agriculture and the citizens of the state. As we have diversified research and extension programs, the results have been chronicled in the pages of California Agriculture.

With this issue, the magazine marks a half century of public service in extending important research. To commemorate the magazine's 50th anniversary, we offer a special historical section beginning on page 20 . We invite you to read these pages and see for yourself how the Division has kept pace with the changing needs of its diverse and increasingly urbanized people. 